\title{
Interferon lambda 3/4 polymorphisms are associated with AIDS-related Kaposi's sarcoma
}

\author{
Stéphanie Bibert ${ }^{\mathrm{a}}$, Agnieszka Wójtowicz ${ }^{\mathrm{a}}$, Patrick Tafféb, \\ Philip E. Tarr ${ }^{\mathrm{c}}$, Enos Bernasconi ${ }^{\mathrm{d}}$, Hansjakob Furrer ${ }^{\mathrm{e}}$, \\ Huldrych F. Günthard ${ }^{\text {f,g }}$, Matthias Hoffmann ${ }^{\text {h }}$, Laurent Kaiseri, \\ Michael Osthoffi, Jacques Fellay ${ }^{\mathrm{k}, \mathrm{l}}$, Matthias Cavassini ${ }^{\mathrm{a}}$, \\ Pierre-Yves Bochud ${ }^{\mathrm{a}}$, the Swiss HIV Cohort Study*
}

\begin{abstract}
Background: Kaposi's sarcoma, the most common AIDS-related cancer, represents a major public concern in resource-limited countries. Single nucleotide polymorphisms within the Interferon lambda 3/4 region (IFNL3/4) determine the expression, function of IFNL4, and influence the clinical course of an increasing number of viral infections.

Objectives: To analyze whether IFNL3/4 variants are associated with susceptibility to AIDS-related Kaposi's sarcoma among MSM enrolled in the Swiss HIV Cohort Study (SHCS).

Methods: The risk of developing Kaposi's sarcoma according to the carriage of IFNL3/4 SNPs rs8099917 and rs12980275 and their haplotypic combinations was assessed by using cumulative incidence curves and Cox regression models, accounting for relevant covariables.

Results: Kaposi's sarcoma was diagnosed in 221 of 2558 MSM Caucasian SHCS participants. Both rs 12980275 and rs8099917 were associated with an increased risk of Kaposi's sarcoma (cumulative incidence 15 versus $10 \%, P=0.01$ and 16 versus $10 \%$, $P=0.009$, respectively). Diplotypes predicted to produce the active P70 form (cumulative incidence 16 versus $10 \%, P=0.01$ ) but not the less active S70 (cumulative incidence 11 versus $10 \%, P=0.7$ ) form of IFNL4 were associated with an increased risk of Kaposi's sarcoma, compared with those predicted not to produce IFNL4. The associations remained significant in a multivariate Cox regression model after adjustment for age at infection, combination antiretroviral therapy, median $\mathrm{CD} 4^{+} \mathrm{T}$-cell count
\end{abstract}

\footnotetext{
anfectious Diseases Service, Department of Medicine, ${ }^{b}$ Institute for Social and Preventive Medicine, University (IUMSP), Lausanne University Hospital, Lausanne, ${ }^{\mathrm{C}}$ Department of Medicine, Kantonspital Baselland, University of Basel, Bruderholz, ${ }^{\mathrm{d} D i v i s i o n}$ of Infectious diseases, Regional hospital of Lugano, Lugano, ${ }^{e}$ Department of Infectious Diseases, Bern University Hospital, University of Bern, Bern, Division of Infectious Diseases and Hospital Epidemiology, University Hospital Zurich, University of Zurich, gInstitute of Medical Virology, University of Zurich, Zurich, ' Division of Infectious Diseases and Hospital Epidemiology, Department of Internal Medicine, Cantonal Hospital St. Gallen, St. Gallen, 'Laboratory of Virology, Division of Infectious Diseases and Division of Laboratory Medicine, University Hospital of Geneva and Medical School, University of Geneva, Geneva, 'ंDivision of Infectious Diseases and Hospital Epidemiology and Department of Internal Medicine, University Hospital Basel, Basel, "'Global Health Institute, School of Life Sciences, Ecole Polytechnique Fédérale de Lausanne, and 'Precision Medicine unit, Lausanne University Hospital, Lausanne, Switzerland.

Correspondence to Pierre-Yves Bochud, MD, Infectious Diseases Service, CHUV, Rue du Bugnon 46, 1011 Lausanne,

Switzerland.

Tel: +41 2131410 26; fax: +4121314 40 60; e-mail: Pierre-Yves.Bochud@chuv.ch

* Members of the Swiss HIV Cohort Study group are listed in the appendix.

Received: 29 May 2018; accepted: 12 August 2018.
}

DOI:10.1097/QAD.0000000000002004

ISSN 0269-9370 Copyright ( $) 2018$ Wolters Kluwer Health, Inc. All rights reserved. Copyright @ 2018 Wolters Kluwer Health, Inc. All rights reserved. 
nadir and $\mathrm{CD}^{+}$slopes (hazard ratio $1.42,95 \%$ confidence interval 1.06-1.89, $P=0.02$ for IFLN P70 versus no IFNL4).

Conclusion: This study reports for the first time an association between IFNL3/4 polymorphisms and susceptibility to AIDS-related Kaposi's sarcoma.

Copyright (๖ 2018 Wolters Kluwer Health, Inc. All rights reserved.

AIDS 2018, 32:2759-2765

\section{Keywords: AIDS, HIV, interferon lambda 3, immunogenetics, Kaposi's sarcoma, polymorphism}

\section{Introduction}

Kaposi's sarcoma was initially described by Moritz Kaposi [1] in 1872 as a rare and relatively indolent angioproliferative neoplasm affecting elderly men from countries surrounding the Mediterranean Sea (classical form of Kaposi's sarcoma). Another form was described in subSaharan Africa in the 1950s, which affects middle aged adults and children (endemic form of Kaposi's sarcoma) [2]. In 1981, a potentially fatal form of Kaposi's sarcoma was described among young homosexual men as a characteristic feature of the AIDS epidemics (epidemic form of Kaposi's sarcoma), a population in which it still represents one of the most common AIDS-related cancer [3-8]. An invasive form can also affect patients with nonAIDS immune suppression, in particular, solid organ transplant (SOT) recipients (iatrogenic form of Kaposi's sarcoma, reviewed in [2]).

Although the four epidemiological forms of Kaposi's sarcoma share the same histological characteristics [9] and are all subsequent to human herpes virus 8 (HHV-8) infection [10,11], the development of distinct clinical features seems to rely on a combination of host and environmental factors. Although HIV-related or drugrelated immune suppression is inherent to the epidemic and iatrogenic forms (AIDS and SOT), genetic predisposition may be required for the classical (Mediterranean and Jewish ancestry) [12-14] and endemic forms (subSaharan Africa) [15]. Hormonal factors [16-19] have been proposed to explain the male predominance of all forms of Kaposi sarcoma. Environmental conditions relative to potential routes of infection (soil, animal vectors) have been proposed to influence susceptibility to different forms of Kaposi's sarcoma [20-25]. Although viral factors may influence clinical presentation, evidence for a definite link between a specific subtype strain and a Kaposi's sarcoma type is still lacking [26-29].

Several investigators have analyzed the role of host genetic factors in susceptibility to Kaposi's sarcoma within a given population at risk. The most relevant was a polymorphism within the $I L-6$ promoter, which was consistently more frequent among Kaposi's sarcoma patients versus controls in two cohorts of AIDS patients [30,31] and a small cohort of SOT patients [32]. Polymorphisms in other candidate genes (e.g. MHC-related or cytokines/ chemokines-related genes) were associated with Kaposi's sarcoma in studies of AIDS patients [31,33-35] and two studies including patients with the classical form of Kaposi's sarcoma $[36,37]$.

Single nucleotide polymorphisms (SNPs) in the region encoding for interferon lambda 3 (IFNL3 previously named IL-28B) and interferon lambda 4 (IFNL4) represent major factors in the ability of individuals to clear hepatitis $\mathrm{C}$ virus (HCV) [38-41]. They determine different haplotypic combinations (diplotypes) based on their capacity to produce IFNL4, that is, no production versus production as an active $\mathrm{P} 70$ or less active $\mathrm{S} 70$ form [42-44]. IFNL3/4 SNPs are increasingly known to influence the susceptibility to or the clinical course of infections due to viruses other than HCV, including herpes viruses such as cytomegalovirus (CMV) and Epstein-Barr virus (EBV) [45-47]. Here, we hypothesize that IFNL3/4 polymorphisms influence the risk of AIDS patients to develop Kaposi's sarcoma.

\section{Material and methods}

\section{Study patients}

The Swiss HIV Cohort Study (SHCS) is an ongoing multicenter prospective study of HIV-infected patients enrolled at seven major Swiss hospitals and their local affiliated centers since 1988 [48]. For the present study, Caucasian MSM with available DNA for genotyping and a written informed consent for genetic studies were included. In order to account for the time at risk, only patients with an estimated date of HIV infection were selected [49]. Demographic characteristics including age, duration of HIV infection, $\mathrm{CD} 4^{+}$T-cell count nadir, other opportunistic infections, HIV maximal viral load and HAART use were extracted from the SHCS clinical database. Kaposi's sarcoma was defined according to predefined clinical and histological criteria.

\section{Single nucleotide polymorphism genotyping}

Genomic DNA isolated either from blood or cell pellets was genotyped for haplotype tagging SNPs rs 8099917 and rs 12980275 using a customized GoldenGate 
Genotyping Assay on Veracode platform (Illumina, San Diego, California, USA). These SNPs were used as surrogates for rs368234815 and rs117648444, respectively, based on previously published linkage disequilibrium (LD) values, which were shown to determine the three main diplotypic forms of IFNL4.

\section{Statistical analysis}

Statistical analyses were performed using Stata (version 14.2, StataCorp LP, College Station, Texas, USA). Hardy-Weinberg equilibrium (HWE) was verified using the program genhw implemented in Stata. Haplotypes were inferred using Phase and grouped according to their ability to express the different forms of IFNL3/4 as described previously [43]. The association of IFNL3/4 polymorphisms with Kaposi's sarcoma was assessed by $25-$ year cumulative incidence curves as well as univariable and multivariable Cox regression models, using the estimated date of HIV infection as a starting point, with censoring at death and/or lost follow-up. The proportional hazard assumption was verified by using the stphtest command implemented in Stata. Estimated dates of HIV infection and $\mathrm{CD} 4^{+}$slopes in both incident and prevalent cases were obtained by using a joint back calculation model as described previously [50].

\section{Results}

The study included 2558 MSM patients among whom 221 developed Kaposi's sarcoma (8.6\%, Supplementary Table 1, http://links.lww.com/QAD/B360). Considering the whole patient population, the median age at estimated date of HIV infection was 34 (interquartile range, IQR $=13$ ). The median $\mathrm{CD}^{+}{ }^{+} \mathrm{T}$-cell nadir was 181 cells $/ \mathrm{mm}^{3}(\mathrm{IQR}=174)$ and the maximal HIV RNA viral load $5.12 \log _{10}$ copies $/ \mathrm{ml} \quad(\mathrm{IQR}=0.85)$. Most individuals started HAART therapy during follow-up (97\%). An active HBV infection was recorded in 10\% of patients and HCV serology was positive in $8 \%$.

The minor allele frequencies (MAFs) of IFNL3/4 rs 12980275 and rs8099917 were 0.30 and 0.20 , respectively, and both were at HWE. Carriage of rs12980275 and rs8099917 were both associated with an increased risk of Kaposi's sarcoma (cumulative incidence 15 versus $10 \%, P=0.01$ and cumulative incidence 16 versus $10 \%, P=0.009$, respectively, Fig. 1). Diplotypes predicted to produce the active P70 form of IFNL4, but not those predicted to produce the less active $\mathrm{S} 70$ form were associated with an increased risk of Kaposi's sarcoma, compared with diplotypes not producing IFNL4 (cumulative incidence 16 versus $10 \%$, $P=0.01$ and cumulative incidence 11 versus $10 \%$, $P=0.7$, respectively).
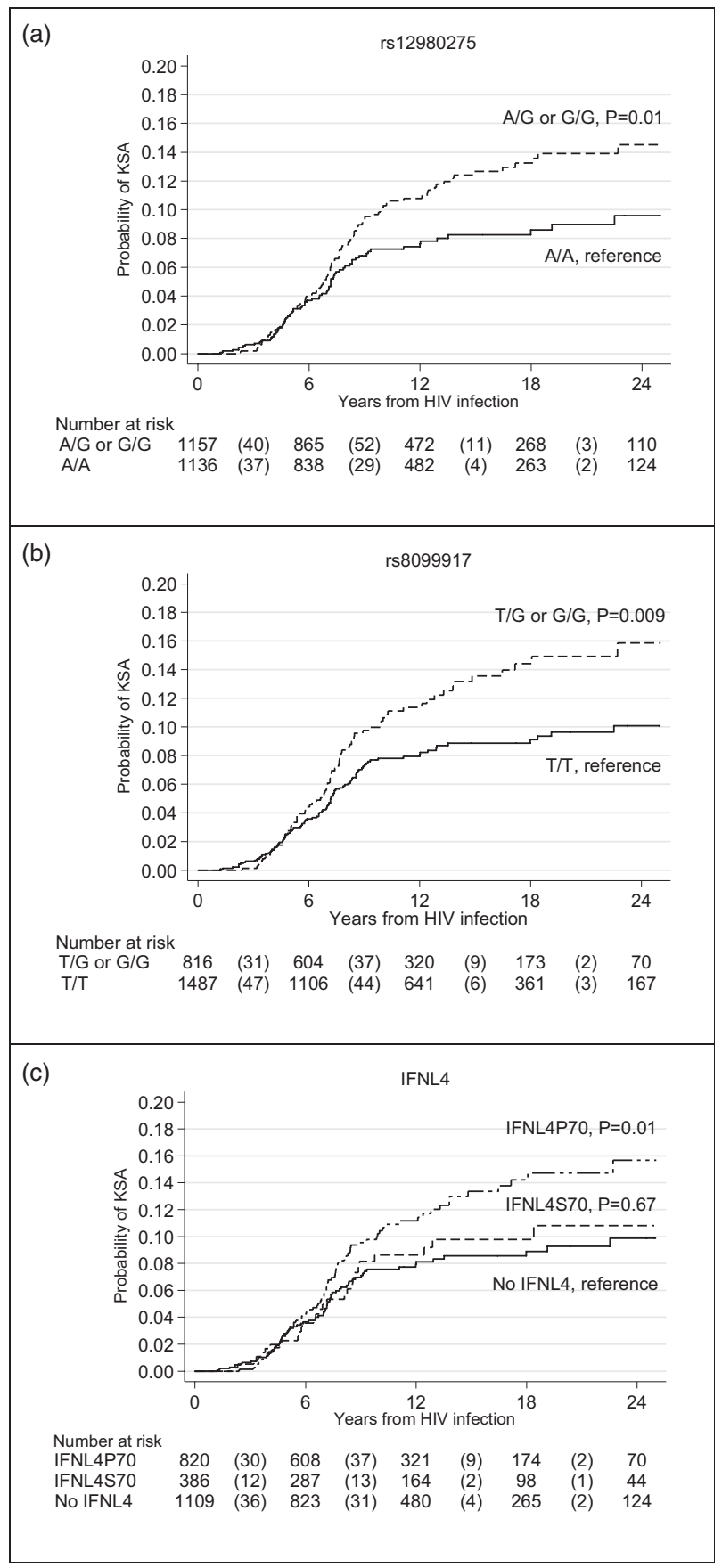

Fig. 1. Cumulative incidence of Kaposi's sarcoma according to IFNL4 rs12980275 (a), IFNL3/4 rs8099917 (b), IFNL4 diplotypes (c) in MSM participants of the Swiss HIV Cohort Study. The estimated date of HIV infection was used as a starting point with censoring at death or lost follow-up. Numbers in parenthesis indicate the number of patients with Kaposi's sarcoma in each group of patients. $P$ values were calculated by log-rank test, dominant mode.

The association between IFNL4P70-producing diplotypes and Kaposi's sarcoma remained significant in a multivariate Cox regression model, accounting for age at infection, HAART, median $\mathrm{CD}^{+}{ }^{+} \mathrm{T}$-cell count nadir and 
Table 1. Independent risk factors associated with Kaposi's sarcoma among MSM.

\begin{tabular}{|c|c|c|c|c|}
\hline \multirow[b]{2}{*}{ Variable } & \multicolumn{2}{|c|}{ Univariate } & \multicolumn{2}{|c|}{ Multivariate } \\
\hline & Hazard ratio $(95 \% \mathrm{Cl})^{\mathrm{a}}$ & $P$ & Hazard ratio $(95 \% \mathrm{Cl})$ & $P$ \\
\hline Age at estimated date of infection ${ }^{b}$ & $1.01(1.00-1.03)$ & 0.07 & $1.01(1.00-1.03)$ & 0.04 \\
\hline $\mathrm{CD}^{+}{ }^{+}$nadir $\left(<200\right.$ cells $\left./ \mathrm{mm}^{3}\right)$ & $2.56(1.87-3.51)$ & $<0.001$ & $2.02(1.45-2.82)$ & $<0.001$ \\
\hline $\mathrm{CD}^{+}$slope $^{\mathrm{c}}$ (continuous) & $0.69(0.58-0.81)$ & $<0.001$ & $0.71(0.60-0.85)$ & $<0.001$ \\
\hline Maximal HIV RNA load (continuous) & $1.21(1.01-1.44)$ & 0.04 & & \\
\hline HAART (time-dependant covariate) & $0.43(0.31-0.60)$ & $<0.001$ & $0.36(0.25-0.51)$ & $<0.001$ \\
\hline HCV co-infection $^{d}$ & $0.92(0.55-1.53)$ & 0.75 & & \\
\hline Active HBV infection ${ }^{\mathrm{e}}$ & $1.32(0.78-2.24)$ & 0.30 & & \\
\hline \multicolumn{5}{|l|}{ SNPs } \\
\hline IFNL3/4 rs12980275 (AA versus AG or GG) & $1.36(1.04-1.77)$ & 0.03 & & \\
\hline IFNL3/4 rs8099917 (TT versus TG or GG) & $1.40(1.07-1.82)$ & 0.01 & & \\
\hline \multicolumn{5}{|l|}{ Diplotypes } \\
\hline No IFNL4 & Reference & & Reference & \\
\hline IFNL4 P70 & $1.40(1.05-1.87)$ & 0.02 & $1.42(1.06-1.89)$ & 0.02 \\
\hline IFNL4 S70 & $1.09(0.74-1.61)$ & 0.67 & $1.11(0.75-1.64)$ & 0.61 \\
\hline
\end{tabular}

$\mathrm{Cl}$, confidence interval; HBV, hepatitis B virus; $\mathrm{HCV}$, hepatitis $\mathrm{C}$ virus.

${ }^{a}$ The proportional hazard assumption was verified for all variables with the exception of CD4 ${ }^{+}$slope. However, the association between IFNL4P70 and Kaposi's sarcoma was similar when $\mathrm{CD}^{+}{ }^{+}$slope was removed from the multivariate model (hazard ratio $1.33,95 \% \mathrm{Cl} 1.07-1.65, P=0.01$ ). ${ }^{\mathrm{b}}$ Per 1 year.

${ }^{\mathrm{C}}$ Rate of $\mathrm{CD} 4^{+}$depletion in the absence of HAART.

dReflected by HCV serology.

e Defined by the presence of HBsAg in the blood.

$\mathrm{CD} 4{ }^{+}$slopes (hazard ratio $1.42,95 \%$ confidence interval (95\% CI) $1.06-1.89, P=0.02$; Table 1).

\section{Discussion}

Polymorphisms in the region encoding for IFNL3 and 4 have been identified for their major role in the ability of individuals to clear HCV. Increasing evidence suggests that such polymorphisms can also influence the clinical course of infections due to viruses other than $\mathrm{HCV}$ [51,52], in particular those from the Herpesviridae family [CMV [45,46], EBV [47] and herpes simplex virus (HSV) [53]]. In this study, we report for the first time an association between IFNL3/4 polymorphisms and susceptibility to Kaposi's sarcoma among HIV-infected MSM.

An increasing number of in-vitro studies support the role of IFNL in the immunopathogenesis of viral infections due to viruses other than HCV. A series of cell culturebased models have shown that IFNL3/4 controls the replication of viruses such as human [54] and murine CMV [55], HSV2 [56], HBV [57], dengue virus [58], human metapneumovirus (hMPV) [59], influenza virus [60-62], lymphocytic choriomeningitis virus (LCMV) [63] and Sendai virus [64]. Although no studies have analyzed the direct role of IFNL on HHV-8 replication, the involvement of IFNL in its immunopathogenesis is supported indirectly by at least two studies. Those showed that HHV-8 can inhibit interferon transcription by the production of interferon regulatory factor (IRF) homologues as well as block the expression of interferon-stimulating genes (ISGs) through Janus kinasesignal transducer and activator of transcription pathway interference $[65,66]$.

Haplotypic combinations predicted to produce the P70 active, but not the S70 less active form of IFNL4, were associated with an increased risk of Kaposi's sarcoma. This is consistent with the association reported in other viral infections; SNPs encoding or tagging the P70 form of IFNL4 induce a higher susceptibility to HCV $[42,44]$, CMV [45,46], EBV [47] and HSV [53]. This paradoxical effect of IFNL4 may rely on at least three different mechanisms. First, IFNL4 may compete with the other IFNLs through a mechanism involving the overexpression of its IFNLR1 subunit [67]. Second, IFNL4 may induce a refractory state of the pathway because of persistent ISG expression [43]. Third, individuals expressing the active form of IFNL4 may in return produce lower amount of IFNL3, with subsequent reduced ISG expression $[42,68,69]$. The resulting balance between IFNL3 and IFNL4 expression may be particularly relevant in Kaposi's sarcoma lesions, given the presence of numerous recruited plasmacytoid dendritic cells (pDC), which represent the most important producer of these cytokines [70].

Beyond antiviral properties, IFNLs may also exert antitumoral activities including a growth inhibitory effect and apoptosis of tumor cells, as recently described in culture of melanoma [71], lung adenocarcinoma [72,73], neuroendocrine cancer [74], colorectal carcinoma [75], esophageal carcinoma [76] and hepatocellular carcinoma [77] cells or in mouse models of melanoma [78], colon adenocarcinoma [78] and fibrosarcoma [79]. In humans, the expression of IFNL1 has been negatively correlated 
with the progression of cervical cancer because of papilloma virus [80], suggesting a potential role of this cytokine in cancer immunity. Altogether, these data suggest that polymorphisms in IFNLs may not only influence the immunity against $\mathrm{HHV}-8$, but also the immunity against Kaposi's sarcoma cancer cells.

Like most genetic association studies, our study performed on HIV-infected MSM is constrained by some limitations. Data on HHV-8 seroprevalence are not available in the SHCS cohort, thereby preventing analyses limited to patients with Kaposi's sarcoma but excluding HHV-8-positive individuals who did not develop Kaposi's sarcoma. This limitation may be at least in part compensated by the fact that the prevalence of HHV-8 among MSM is elevated $[81,82]$ and that the prevalence of Kaposi's sarcoma and HHV-8 is very well correlated in HIV-infected populations [83-85]. Most likely, the currently chosen analytic approach would underestimate but not overestimate the effect of IFNL polymorphisms.

In summary, our data show an association between IFNL3/4 polymorphisms and the development of Kaposi's sarcoma among HIV+ MSM patients. This new finding confirms that IFNLs mediate antiviral responses against a growing range of viruses.

\section{Acknowledgements}

The authors thank all patients from the SHCS, as well as collaborators from the clinical, laboratory and data centers and all study nurses.

\section{Conflicts of interest}

There are no conflicts of interest.

\section{Financial support}

P.Y.B. is supported by the Swiss National Science Foundation (324730_165954 and 33IC30_179636), the Leenaards Foundation, the Santos-Suarez Foundation and the Loterie Romande. Furthermore, this project was supported by SHCS project No 613. The Swiss HIV Cohort Study is supported by the Swiss National Science Foundation (grant \#177499), by SHCS project \#803 and by the SHCS research foundation.

\section{Author's contributions}

S.B. performed sample management, DNA extraction, candidate SNP genotyping, statistical analysis and wrote the manuscript. A.W. performed SNP genotyping for the SHCS patients and data management. P.T. contributed to statistical analyses. Members of the SHCS group including, P.E.T., E.B., H.F., H.F.G., M.H., L.K., M.O., J.F., M.C. were directly involved in the clinical care of SHCS patients and data acquisition. P.Y.B. designed the SHCS genetic project, obtained funding, supervised genotyping, performed data management and statistical analysis and wrote the manuscript. All authors critically revised the manuscript.

\section{References}

1. Kaposi M. Idiopathisches multiples Pigmentsarcom der Haut. Arch Dermatol Syphilol 1872; 4:265.

2. Mesri EA, Cesarman E, Boshoff C. Kaposi's sarcoma and its associated herpesvirus. Nat Rev Cancer 2010; 10:707-719.

3. Goedert JJ. The epidemiology of acquired immunodeficiency syndrome malignancies. Semin Oncol 2000; 27:390-401.

4. Grulich $A E$, van Leeuwen MT, Falster MO, Vajdic CM. Incidence of cancers in people with HIV/AIDS compared with immunosuppressed transplant recipients: a meta-analysis. Lancet 2007; 370:59-67.

5. Ledergerber B, Telenti A, Egger M. Risk of HIV related Kaposi's sarcoma and non-Hodgkin's lymphoma with potent antiretroviral therapy: prospective cohort study. Swiss HIV Cohort Study. BMJ 1999; 319:23-24.

6. Ledergerber B, Egger M, Erard V, Weber R, Hirschel B, Furrer H, et al. AIDS-related opportunistic illnesses occurring after initiation of potent antiretroviral therapy: the Swiss HIV Cohort Study. JAMA 1999; 282:2220-2226.

7. Franceschi S, Maso LD, Rickenbach M, Polesel I, Hirschel B, Cavassini M, et al. Kaposi sarcoma incidence in the Swiss HIV Cohort Study before and after highly active antiretroviral therapy. Br J Cancer 2008; 99:800-804.

8. Sullivan SG, Hirsch HH, Franceschi S, Steffen I, Amari EB, Mueller NJ, et al. Kaposi sarcoma herpes virus antibody response and viremia following highly active antiretroviral therapy in the Swiss HIV Cohort study. AIDS 2010; 24:2245-2252.

9. Ablashi DV, Chatlynne LG, Whitman JE Jr, Cesarman E. Spectrum of Kaposi's sarcoma-associated herpesvirus, or human herpesvirus 8, diseases. Clin Microbiol Rev 2002; 15:439-464.

10. Chang Y, Cesarman E, Pessin MS, Lee F, Culpepper J, Knowles $\mathrm{DM}$, et al. Identification of herpesvirus-like DNA sequences in AIDS-associated Kaposi's sarcoma. Science 1994; 266:18651869.

11. Russo JJ, Bohenzky RA, Chien MC, Chen J, Yan M, Maddalena $\mathrm{D}$, et al. Nucleotide sequence of the Kaposi sarcoma-associated herpesvirus (HHV8). Proc Natl Acad Sci U S A 1996; 93:1486214867.

12. Camcioglu Y, Picard C, Lacoste V, Dupuis S, Akcakaya N, Cokura $\mathrm{H}$, et al. HHV-8-associated Kaposi sarcoma in a child with IFNgammaR1 deficiency. J Pediatr 2004; 144:519-523.

13. Byun M, Abhyankar A, Lelarge V, Plancoulaine S, Palanduz A, Telhan $L$, et al. Whole-exome sequencing-based discovery of STIM1 deficiency in a child with fatal classic Kaposi sarcoma. J Exp Med 2010; 207:2307-2312.

14. Byun M, Ma CS, Akcay A, Pedergnana V, Palendira U, Myoung $J$, et al. Inherited human OX40 deficiency underlying classic Kaposi sarcoma of childhood. I Exp Med 2013; 210:1743-1759.

15. Aavikko M, Kaasinen E, Nieminen JK, Byun M, Donner I, Mancuso R, et al. Whole-genome sequencing identifies STAT4 as a putative susceptibility gene in classic Kaposi sarcoma. / Infect Dis 2015; 211:1842-1851.

16. Ziegler JL, Katongole-Mbidde E, Wabinga H, Dollbaum CM. Absence of sex-hormone receptors in Kaposi's sarcoma. Lancet 1995; 345:925.

17. Klein SL. The effects of hormones on sex differences in infection: from genes to behavior. Neurosci Biobehav Rev 2000; 24:627-638.

18. Bouscarat F, Dazza MC, Melchior JC, Bouvet E. Kaposi's sarcoma and sex hormones. AIDS 1997; 11:687-688.

19. Lunardi-Iskandar $Y$, Bryant JL, Blattner WA, Hung CL, Flamand $\mathrm{L}$, Gill P, et al. Effects of a urinary factor from women in early pregnancy on HIV-1, SIV and associated disease. Nat Med 1998; 4:428-434.

20. Ascoli V, Zambon P, Manno D, Guzzinati S, Zorzi M, Arca B, et al. Variability in the incidence of classic Kaposi's sarcoma in the Veneto region, Northern Italy. Tumori 2003; 89:122-124.

21. Cook-Mozaffari P, Newton R, Beral V, Burkitt DP. The geographical distribution of Kaposi's sarcoma and of lymphomas in Africa before the AIDS epidemic. $\mathrm{Br}$ J Cancer 1998; 78:1521-1528. 
22. Ziegler JL. Endemic Kaposi's sarcoma in Africa and local volcanic soils. Lancet 1993; 342:1348-1351.

23. Montella M, Franceschi S, Geddes M, Arniani S, Cocchiarella G. Classic Kaposi's sarcoma and volcanic soil in southern Italy. Lancet 1996; 347:905.

24. Simonart T. Role of environmental factors in the pathogenesis of classic and African-endemic Kaposi sarcoma. Cancer Lett 2006; 244:1-7.

25. Henke-Gendo C, Schulz TF. Transmission and disease association of Kaposi's sarcoma-associated herpesvirus: recent developments. Curr Opin Infect Dis 2004; 17:53-57.

26. Hsu YH, Kuo WL, Su IJ. Clinicopathologic study of Kaposi's sarcoma and strain analysis of human herpesvirus 8 (HHV-8) DNA in the Hua-Lien area of eastern Taiwan. J Formos Med Assoc 2001; 100:449-454.

27. Kakoola DN, Sheldon J, Byabazaire N, Bowden RJ, KatongoleMbidde E, Schulz TF, et al. Recombination in human herpesvirus-8 strains from Uganda and evolution of the K15 gene. J Gen Virol 2001; 82 (Pt 10):2393-2404

28. Lacoste V, Judde JG, Briere J, Tulliez M, Garin B, Kassa-Kelembho E, et al. Molecular epidemiology of human herpesvirus 8 in Africa: both B and A5 K1 genotypes, as well as the M and P genotypes of K14.1/K15 loci, are frequent and widespread. Virology 2000; 278:60-74.

29. Stebbing J, Wilder N, Ariad S, Abu-Shakra M. Lack of intrapatient strain variability during infection with Kaposi's sarcoma-associated herpesvirus. Am J Hematol 2001; 68:133-134.

30. Foster CB, Lehrnbecher T, Samuels S, Stein S, Mol F, Metcalf JA, et al. An IL6 promoter polymorphism is associated with a lifetime risk of development of Kaposi sarcoma in men infected with human immunodeficiency virus. Blood 2000; 96:25622567.

31. Aissani B, Wiener HW, Zhang K, Kaslow RA, Ogwaro KM, Shrestha $\mathrm{S}$, et al. A candidate gene approach for virally induced cancer with application to HIV-related Kaposi's sarcoma. Int J Cancer 2014; 134:397-404.

32. Gazouli M, Zavos G, Papaconstantinou I, Lukas JC, Zografidis A, Boletis J, et al. The interleukin-6-174 promoter polymorphism is associated with a risk of development of Kaposi's sarcoma in renal transplant recipients. Anticancer Res 2004; 24 (2C):1311-1314.

33. Gaya A, Esteve A, Casabona J, McCarthy JJ, Martorell J, Schulz $\mathrm{TF}$, et al. Amino acid residue at position 13 in HLA-DR beta chain plays a critical role in the development of Kaposi's sarcoma in AIDS patients. AIDS 2004; 18:199-204.

34. Aissani B, Boehme AK, Wiener HW, Shrestha S, Jacobson LP, Kaslow RA. SNP screening of central MHC-identified HLADMB as a candidate susceptibility gene for HIV-related Kaposi's sarcoma. Genes Immun 2014; 15:424-429.

35. Lehrnbecher TL, Foster CB, Zhu S, Venzon D, Steinberg SM, Wyvill $\mathrm{K}$, et al. Variant genotypes of FcgammaRIIIA influence the development of Kaposi's sarcoma in HIV-infected men. Blood 2000; 95:2386-2390.

36. Brown EE, Fallin D, Ruczinski I, Hutchinson A, Staats B, Vitale F, et al. Associations of classic Kaposi sarcoma with common variants in genes that modulate host immunity. Cancer Epidemiol Biomarkers Prev 2006; 15:926-934.

37. Tornesello ML, Buonaguro L, Cristillo M, Biryahwaho B, Downing R, Hatzakis A, et al. MDM2 and CDKN1A gene polymorphisms and risk of Kaposi's sarcoma in African and Caucasian patients. Biomarkers 2011; 16:42-50.

38. Ge D, Fellay J, Thompson AJ, Simon JS, Shianna KV, Urban TJ, et al. Genetic variation in IL28B predicts hepatitis $C$ treatmentinduced viral clearance. Nature 2009; 461:399-401.

39. Suppiah V, Moldovan M, Ahlenstiel G, Berg T, Weltman M, Abate ML, et al. IL28B is associated with response to chronic hepatitis C interferon-alpha and ribavirin therapy. Nat Genet 2009; 41:1100-1104.

40. Tanaka Y, Nishida N, Sugiyama M, Kurosaki M, Matsuura K, Sakamoto $N$, et al. Genome-wide association of IL28B with response to pegylated interferon-alpha and ribavirin therapy for chronic hepatitis C. Nat Genet 2009; 41:11051109.

41. Rauch A, Kutalik Z, Descombes P, Cai T, Di lulio J, Mueller T, et al. Genetic variation in IL28B is associated with chronic hepatitis $\mathrm{C}$ and treatment failure: a genome-wide association study. Gastroenterology 2010; 138:1338.e1-1345.e7.
42. Bibert S, Roger T, Calandra T, Bochud M, Cerny A, Semmo N, et al., Swiss Hepatitis C Cohort Study. IL28B expression depends on a novel TT/-G polymorphism which improves HCV clearance prediction. J Exp Med 2013; 210:1109-1116.

43. Terczynska-Dyla E, Bibert S, Duong FH, Krol I, Jorgensen S, Collinet $\mathrm{E}$, et al. Reduced IFNlambda4 activity is associated with improved HCV clearance and reduced expression of interferon-stimulated genes. Nat Commun 2014; 5:5699.

44. Prokunina-Olsson L, Muchmore B, Tang W, Pfeiffer RM, Park H, Dickensheets $\mathrm{H}$, et al. A variant upstream of IFNL3 (IL28B) creating a new interferon gene IFNL4 is associated with impaired clearance of hepatitis C virus. Nat Genet 2013; 45:164171.

45. Manuel O, Wojtowicz A, Bibert S, Mueller NJ, van Delden C, Hirsch HH, et al., Swiss Transplant Cohort Study. Influence of IFNL3/4 polymorphisms on the incidence of cytomegalovirus infection after solid-organ transplantation. J Infect Dis 2015; 211:906-914.

46. Bibert S, Wojtowicz A, Taffe P, Manuel O, Bernasconi E, Furrer $\mathrm{H}$, et al., Swiss HIV Cohort Study. The IFNL3/4 DeltaG variant increases susceptibility to cytomegalovirus retinitis among HIV-infected patients. AIDS 2014; 28:1885-1889.

47. Akay $\mathrm{E}$, Patel $\mathrm{M}$, Conibear T, Chaggar T, Haque T. Interleukin 28B gene polymorphisms and Epstein-Barr virus-associated lymphoproliferative diseases. Intervirology 2014; 57:112-115.

48. Swiss HIV Cohort Study. Schoeni-Affolter F, Ledergerber B, Rickenbach M, Rudin C, Gunthard HF, et al. Cohort profile: the Swiss HIV Cohort study. Int J Epidemiol 2010; 39:1179_ 1189

49. Taffe P, May M, Swiss HIV Cohort Study. A joint back calculation model for the imputation of the date of HIV infection in a prevalent cohort. Stat Med 2008; 27:4835-4853.

50. Loeuillet C, Deutsch S, Ciuffi A, Robyr D, Taffe P, Munoz M, et al. In vitro whole-genome analysis identifies a susceptibility locus for HIV-1. PLoS biology 2008; 6:e32.

51. Trevino A, Lopez M, Vispo E, Aguilera A, Ramos JM, Benito R, et al., HTLV Spanish Study Group. Development of tropical spastic paraparesis in human T-lymphotropic virus type 1 carriers is influenced by interleukin 28B gene polymorphisms. Clin Infect Dis 2012; 55:e1-e4.

52. Angulo J, Pino K, Echeverria-Chagas N, Marco C, MartinezValdebenito $\mathrm{C}$, Galeno $\mathrm{H}$, et al. Association of single-nucleotide polymorphisms in IL28B, but not TNF-alpha, with severity of disease caused by Andes virus. Clin Infect Dis 2015; 61: e62-e69.

53. Griffiths SJ, Koegl M, Boutell C, Zenner HL, Crump CM, Pica F, et al. A systematic analysis of host factors reveals a Med23interferon-lambda regulatory axis against herpes simplex virus type 1 replication. PLoS Pathog 2013; 9:e1003514.

54. Egli A, Levin A, Santer DM, Joyce M, O'Shea D, Thomas BS, et al. Immunomodulatory function of interleukin 28B during primary infection with cytomegalovirus. I Infect Dis 2014; 210:717-727.

55. Brand S, Beigel F, Olszak T, Zitzmann K, Eichhorst ST, Otte JM, et al. IL-28A and IL-29 mediate antiproliferative and antiviral signals in intestinal epithelial cells and murine CMV infection increases colonic IL-28A expression. Am J Physiol Gastrointest Liver Physiol 2005; 289:G960-G968.

56. Zhou L, Li JL, Zhou Y, Liu JB, Zhuang K, Gao JF, et al. Induction of interferon-lambda contributes to TLR3 and RIG-I activationmediated inhibition of herpes simplex virus type 2 replication in human cervical epithelial cells. Mol Hum Reprod 2015; 21:917-929.

57. Robek MD, Boyd BS, Chisari FV. Lambda interferon inhibits hepatitis B and C virus replication. J Virol 2005; 79:3851-3854.

58. Palma-Ocampo HK, Flores-Alonso JC, Vallejo-Ruiz V, ReyesLeyva J, Flores-Mendoza L, Herrera-Camacho I, et al. Interferon lambda inhibits dengue virus replication in epithelial cells. Virol / 2015; 12:150.

59. Banos-Lara Mdel R, Harvey L, Mendoza A, Simms D, Chouljenko $\mathrm{VN}$, Wakamatsu $\mathrm{N}$, et al. Impact and regulation of lambda interferon response in human metapneumovirus infection. J Virol 2015; 89:730-742.

60. Mordstein M, Kochs G, Dumoutier L, Renauld JC, Paludan SR, Klucher K, et al. Interferon-lambda contributes to innate immunity of mice against influenza $A$ virus but not against hepatotropic viruses. PLoS pathogens 2008; 4:e1000151. 
61. Mordstein M, Neugebauer E, Ditt V, Jessen B, Rieger T, Falcone $\checkmark$, et al. Lambda interferon renders epithelial cells of the respiratory and gastrointestinal tracts resistant to viral infections. J Virol 2010; 84:5670-5677.

62. Jewell NA, Cline T, Mertz SE, Smirnov SV, Flano E, Schindler C, et al. Lambda interferon is the predominant interferon induced by influenza A virus infection in vivo. J Virol 2010; 84:1151511522.

63. Lukacikova L, Oveckova I, Betakova T, Laposova K, Polcicova $\mathrm{K}$, Pastorekova $\mathrm{S}$, et al. Antiviral effect of interferon lambda against lymphocytic choriomeningitis virus. I Interferon Cytokine Res 2015; 35:540-553.

64. Ank N, West H, Bartholdy C, Eriksson K, Thomsen AR, Paludan SR. Lambda interferon (IFN-lambda), a type III IFN, is induced by viruses and IFNs and displays potent antiviral activity against select virus infections in vivo. / Virol 2006; 80:4501-4509.

65. Wen KW, Damania B. Kaposi sarcoma-associated herpesvirus (KSHV): molecular biology and oncogenesis. Cancer Lett 2010; 289:140-150.

66. Djerbi M, Screpanti V, Catrina AI, Bogen B, Biberfeld P, Grandien $A$. The inhibitor of death receptor signaling, FLICE-inhibitory protein defines a new class of tumor progression factors. J Exp Med 1999; 190:1025-1032.

67. Duong FH, Trincucci G, Boldanova T, Calabrese D, Campana $\mathrm{B}$, Krol $\mathrm{I}$, et al. IFN-lambda receptor 1 expression is induced in chronic hepatitis $\mathrm{C}$ and correlates with the IFN-lambda3 genotype and with nonresponsiveness to IFN-alpha therapies. J Exp Med 2014; 211:857-868.

68. Honda M, Shirasaki T, Shimakami T, Sakai A, Horii R, Arai K et al. Hepatic interferon-stimulated genes are differentially regulated in the liver of chronic hepatitis $C$ patients with different interleukin-28B genotypes. Hepatology 2014; 59: 828-838.

69. Fukuhara T, Taketomi A, Motomura T, Okano S, Ninomiya A, Abe $T$, et al. Variants in IL28B in liver recipients and donors correlate with response to peg-interferon and ribavirin therapy for recurrent hepatitis C. Gastroenterology 2010; 139:1577158585 e1-3.

70. Karouni M, Kurban M, Abbas O. Plasmacytoid dendritic cells in skin lesions of classic Kaposi's sarcoma. Arch Dermatol Res 2016; 308:487-492.

71. Lasfar A, Lewis-Antes A, Smirnov SV, Anantha S, Abushahba W, Tian B, et al. Characterization of the mouse IFN-lambda ligandreceptor system: IFN-lambdas exhibit antitumor activity against B16 melanoma. Cancer Res 2006; 66:4468-4477.

72. Tezuka Y, Endo S, Matsui A, Sato A, Saito K, Semba K, et al. Potential antitumor effect of IFN-lambda2 (IL-28A) against human lung cancer cells. Lung cancer 2012; 78:185-192.

73. Yan Y, Zhang J, Liu Y, Zhu T, Yuan L, Ge Y, et al. Inhibition of lung adenocarcinoma transfected with interleukin $28 \mathrm{~A}$ recombinant adenovirus (Ad-mIFN-lambda2) in vivo. Cancer Biother Radiopharm 2013; 28:124-130.

74. Zitzmann K, Brand S, Baehs S, Goke B, Meinecke J, Spottl G, et al. Novel interferon-lambdas induce antiproliferative effects in neuroendocrine tumor cells. Biochem Biophys Res Commun 2006; 344:1334-1341.

75. Hui X, Chen H, Zhang S, Ma X, Wang X, Huang B. Antitumor activities of recombinant human interferon (IFN)-lambda1 in vitro and in xenograft models in vivo for colon cancer. Cancer Lett 2011; 311:141-151.

76. Li Q, Kawamura K, Ma G, Iwata F, Numasaki M, Suzuki N, et al. Interferon-lambda induces G1 phase arrest or apoptosis in oesophageal carcinoma cells and produces antitumour effects in combination with anticancer agents. Eur J Cancer 2010; 46:180-190.
77. Abushahba W, Balan M, Castaneda I, Yuan Y, Reuhl K, Raveche $E$, et al. Antitumor activity of type I and type III interferons in BNL hepatoma model. Cancer Immunol Immunother 2010; 59:1059-1071.

78. Sato A, Ohtsuki M, Hata M, Kobayashi E, Murakami T. Antitumor activity of IFN-lambda in murine tumor models. J Immunol 2006; 176:7686-7694.

79. Numasaki $M$, Tagawa $M$, Iwata $F$, Suzuki $T$, Nakamura $A$, Okada $M$, et al. IL-28 elicits antitumor responses against murine fibrosarcoma. I Immunol 2007; 178:5086-5098.

80. Cannella F, Scagnolari C, Selvaggi C, Stentella P, Recine N, Antonelli $G$, et al. Interferon lambda 1 expression in cervical cells differs between low-risk and high-risk human papillomavirus-positive women. Med Microbiol Immunol 2014; 203: 177-184.

81. Regamey N, Cathomas G, Schwager M, Wernli M, Harr T, Erb P. High human herpesvirus 8 seroprevalence in the homosexual population in Switzerland. / Clin Microbiol 1998; 36:17841786.

82. Liu Z, Fang Q, Zuo J, Chen Y, Minhas V, Wood C, et al. Global epidemiology of human herpesvirus 8 in men who have sex with men: a systematic review and meta-analysis. I Med Virol 2018; 90:582-591.

83. Gao SJ, Kingsley L, Li M, Zheng W, Parravicini C, Ziegler J, et al. KSHV antibodies among Americans, Italians and Ugandans with and without Kaposi's sarcoma. Nat Med 1996; 2:925-928.

84. Martin JN, Ganem DE, Osmond DH, Page-Shafer KA, Macrae $\mathrm{D}$, Kedes $\mathrm{DH}$. Sexual transmission and the natural history of human herpesvirus 8 infection. N Engl J Med 1998; 338:948954.

85. Simpson GR, Schulz TF, Whitby D, Cook PM, Boshoff C, Rainbow $L$, et al. Prevalence of Kaposi's sarcoma associated herpesvirus infection measured by antibodies to recombinant capsid protein and latent immunofluorescence antigen. Lancet 1996; 348:1133-1138.

\section{Appendix}

The members of the Swiss HIV Cohort Study are: Anagnostopoulos A., Battegay M., Bernasconi E., Böni J., Braun D.L., Bucher H.C., Calmy A., Cavassini M., Ciuffi A., Dollenmaier G., Egger M., Elzi L., Fehr J., Fellay J., Furrer H. (Chairman of the Clinical and Laboratory Committee), Fux C.A., Günthard H. (President of the SHCS), Haerry D. (deputy of 'Positive Council'), Hasse B., Hirsch H.H., Hoffmann M., Hösli I., Huber M., Kahlert C., Kaiser L., Keiser O., Klimkait T., Kouyos R.D., Kovari H., Ledergerber B., Martinetti G., Martinez de Tejada B., Marzolini C., Metzner K.J., Müller N., Nicca D., Paioni P., Pantaleo G., Perreau M., Rauch A. (Chairman of the Scientific Board), Rudin C. (Chairman of the Mother \& Child Substudy), Scherrer A.U. (Head of Data Centre), Schmid P., Speck R., Stöckle M., Tarr P., Trkola A., Vernazza P., Wandeler G., Weber R., Yerly S. 